ISSN (print) : 2722-73I6

e-ISSN : :2723-1275

https://ejournal.uhn.ac.id/index.php/humaniora

\title{
RESILIENSI PADA MAHASISWA SELAMA PEMBELAJARAN DARING
}

\author{
Asina Christina Rosito \\ Fakultas Psikologi Universitas HKBP Nammensen, Medan \\ asina.christina国hotmail.com
}

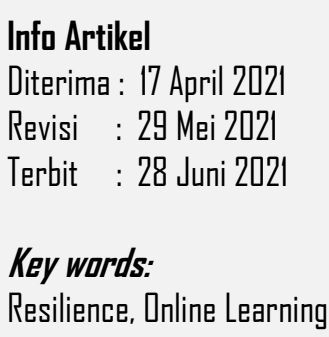

Kata Kunci:

Resiliensi, Pembelajaran Daring

\section{Corresponding Author :}

Asina Christina Rasita,

E-mail :

asina.christina国hotmail.com

\begin{abstract}
The purpose of this study was to abtain an overview of the resilience of students during online learning. Participants in this study were 730 active students from various campuses in Sumatra, Java, and Papua. The research data was collected by distributing the adapted version of The Connor-Davidsan Resilience Scale (CD-RISC). The data analysis technique used were statistical descriptive analysis and categorization of resilience scores and scores of each dimension. The results showed that the mean score for resilience was $96.24(S D=14.75)$, for the dimensions of personal competence, high standard, and tenacity was $31.23(S D=5.22)$, for the dimensions of trust to one's instinct, tolerance of negative affect was 26.II. ( $(S D=4.56)$, for the positive acceptance of change and secure relationship dimensions was $18 . .1$ ( $(S D=3.74$ ), for the control dimension was $11.8 \mathrm{G}(S \mathrm{SD}=2.15)$, and for the spiritual influence dimension was $8.92(S D=1.30)$. Based an the categorization, it was found that there were 474 participants (64.9\%) with high resilience, 247 people (33.8\%) with moderate resilience, and 9 people (1.2\%) with low resilience. Further discussion of the results is presented.
\end{abstract}

\section{Abstrak}

Tujuan dari penelitian ini adalah untuk memperoleh gambaran mengenai resiliensi dari para mahasiswa selama pembelajaran daring. Partisipan dalam penelitian ini adalah 730 arang mahasiswa aktif dari berbagai kampus yang ada di Sumatera, Jawa, dan Papua. Pengumpulan data penelitian dilakukan dengan menyebarkan skala The CannarDavidsan Resilience Scale (CD-RISC) versi adaptasi, secara online. Teknik analisis data yang digunakan adalah melakukan analisis deskriptif statistik dan kategarisasi skar resiliensi dan skar masing-masing dimensi resiliensi. Hasil penelitian menunjukkan bahwa nilai rata-rata untuk skor resiliensi adalah 96.24 (SD = 14.75), untuk dimensi persanal campetence, high standard, dan tenacity adalah 31.23 (SD = 5.2Z), untuk dimensi trust to ane's instinct, tolerance of negative affect adalah Z6.IZ (SD = 4.56), untuk dimensi positive acceptance of change and secure relationship adalah lo.II (SD = 3.74), untuk dimensi cantra/adalah $11.86(S \mathrm{~S}=2.15)$, dan untuk dimensi spiritual influence adalah 8.92 (SD = 1.30). Berdasarkan kategarisasi, diperoleh hasil bahwa 474 arang partisipan (64.9\%) dengan resiliensi yang tinggi, terdapat 247 arang (33.8\%) dengan resiliensi yang sedang, dan ada 9 arang (1.2\%) dengan resiliensi yang rendah. Diskusi tentang hasil dipaparkan lebih lanjut. 


\section{PENDAHULUAN}

Pandemi Cavid IS yang melanda berbagai negara di dunia termasuk Indonesia pada awal tahun 2020, membawa perubahan yang sangat signifikan dalam berbagai aspek kehidupan manusia. Bidang kesehatan benarbenar mengalami porak-poranda dikarenakan virus ini, ada banyak kasus kematian dan kasus terinfeksi positif Covid 19, yang sampai sekarang, pada pertengahan tahun 2021, masih terus terjadi peningkatan dalam jumlahnya. Para tenaga kesehatan yang berjuang sebagai garda terdepan dalam melawan virus ini, harus berhadapan dengan para pasien yang terknnfirmasi positif Covid 19, dengan menggunakan APD (Alat Pelindung Diri) yang tidak selalu nyaman dipakai, ada yang tidak bisa pulang ke rumah berhari-hari atau bahkan berminggu-minggu bertemu keluarga demi melakukan pelayanan kesehatan yang terbaik, dan tak dipungkiri banyak juga tenaga kesehatan yang terpapar dan terkanfirmasi positif Covid 19 dan bahkan sampai meninggal dunia. Situasi-situasi ini berpotensi menimbulkan kecemasan psikologis dalam diri para tenaga kesehatan.

Sejak pandemi Covid 19 melanda negara kita, tidak hanya sektor kesehatan yang terkena dampaknya, namun juga berbagai sektor lainnya antara lain dalam pendidikan, ekonomi dan sasial. Sebagai dampak dari kebijakan pemerintah untuk melakukan physica/ distancing (antara lain belajar dari rumah, bekerja dari rumah dan beribadah dari rumah) sebagai salah satu upaya memutus penyebaran virus ini, berbagai jenjang pendidikan baik dari tingkat pendidikan anak usia dini, pendidikan menengah, sampai dengan pendidikan tinggi, melakukan pembelajaran secara daring (anline). Dengan kata lain, peserta didik belajar dari rumah masing-masing, dan tidak melakukan pembelajaran tatap muka seperti biasa. Hal ini membawa perubahan signifikan dalam metade belajar dan mengajar yang awalnya mengandakan cara konvensional, harus beralih menjadi pembelajaran menerapkan teknologi digital dan internet. Pelajar harus berusaha belajar secara mandiri dari rumah masingmasing, dimana hal ini tentu tidak mudah, apalagi jika kurang pendampingan dari orangtua (terutama siswa sekalah dasar). Situasi rumit bisa bertambah jika fasilitas yang diperlukan seperti gadget dan jaringan internet ternyata kurang memadai. Selain itu, keterbatasan dalam berinteraksi dengan teman sebaya dan guru atau pengajar dapat juga menambah kesulitan pelajar dalam beradaptasi dengan situasi pembelajaran daring ini. Dapat disimpulkan, bahwa pembelajaran daring ini berpatensi memberikan kesulitan, tantangan, masalah, dan bisa menjadi sumber stress bagi para pelajar.

Dalam sektar perekonomian, pada tahun 2020 lalu, banyak karyawan perusahaan ataupun pabrik yang mengalami pemutusan hubungan kerja, sebagai imbas dari pemberlakukan kebijakan physica/ distancing. Рara pelaku sektor ekonomi mandiri pun terkena imbas, antara lain para driver transportasi online yang mengalami penurunan pemasukan yang drastis selama beberapa bulan pertama pandemi, dikarenakan minimnya masyarakat yang melakukan perjalanan atau yang menggunakan transportasi online karena berada di rumah 
saja. Selain itu, para pelaku usaha mikro pun terkena imbasnya misalnya para pedagang makanan, karena ada kecenderungan masyrakat takut membeli makanan dari luar rumah dan juga karena minimnya mobilitas masyarakat. Dengan demikian, pandemi ini memberi dampak psiknlogis tertentu bagi masyarakat terutama yang terdampak secara ekonomi, dimana mereka harus berhadapan dengan kenyataan pemasukan keuangan yang menurun, sementara kebutuhan hidup harus terpenuhi.

Dalam kehidupan sasial psikolagis, masyarakat pun mengalami dampak. Bagi para keluarga yang kehilangan anggata keluarga dikarenakan oleh Cavid IS, sangatlah tidak mudah menerima kenyataan tersebut. Hal ini dapat memicu stress dan bahkan depresi jika tidak dibarengi dengan dukungan sasial yang memadai. Bagi para penyintas Cavid IS, ada kecenderungan kecemasan yang tinggi dalam beraktivitas di luar rumah ataupun dalam melakukan aktivitas lainnya.

Berdasarkan berbagai hal peristiwa hidup yang dialami oleh manusia selama pandemi Covid IS ini, seperti yang dipaparkan di atas, walaupun belum menggambarkan keseluruhan situasi sulit dan tantangan yang terjadi, dapat disimpulkan bahwa individu memerlukan kemampuan psikologis untuk bangkit dari kesulitan, kegagalan, keterpurukan, dan derita yang dialami. Kemampuan psikolagis untuk bangkit dari situasi-situasi seperti ini disebut dengan resiliensi.

Resiliensi dapat dimaknakan dengan proses dari adaptasi yang positif terhadap situasi yang menantang dan mengancam (Howard \& Jhonson, 2000). Richardson (2002) menjelaskan bahwa resiliensi adalah proses koping terhadap stressar (sumber-sumber stress), kesulitan, perubahan, maupun tantangan yang dipengaruhi oleh faktor protektif.

Resiliensi bukanlah sebuah sifat atau karakteristik individu yang menetap pada diri seseorang, namun merupakan hasil interaksi yang dinamis antara kekuatan dari luar diri individu dengan kekuatan dari dalam diri individu (Perkins \& Caldwell, dalam Hendriani, 2018). Sehingga, dapat disimpulkan bahwa resiliensi bukanlah atribut psikologis yang bersifat statis, namun sebagai sebuah proses dinamis yang berkembang sepanjang waktu dalam rentang kehidupan sesearang (Everall, Altrows \& Paulson, 2006). Zimmerman \& Arunkumar (1994) menambahkan resiliensi merupakan suatu hal yang bersifat multidimensional dimana sifatnya adalah sesuai dengan konteks yang spesifik, dan mencakup berbagai perubahan dalam perkembangan hidup.

Ada beberapa konsep teoretis tentang resiliensi yang berkembang antara lain yang dikemukakan oleh Gratberg (1999) dan oleh Reivich \& Shatte (2002). Gratberg (1999) merumuskan pengertian dari resiliensi sebagai kemampuan manusia untuk menghadapi, mengatasi, menjadi kuat ketika menghadapi rintangan dan hambatan. Menurutnya, setiap manusia mempunyai kemampuan untuk menjadi resilien. Dengan kata lain, setiap 
individu memiliki kapasitas untuk belajar tentang bagaimana menghadapi dan mengatasi hambatan atau tantangan yang dialami dalam kehidupannya. Menurut Reivich dan Shatte (2002), resiliensi menggambarkan kemampuan individu untuk merespon adversity atau trauma yang dihadapi dengan cara-cara yang sehat dan bersifat produktif. Karakteristik umum dari resiliensi antara lain adanya kemampuan untuk menghadapi kesulitan, adanya ketangguhan dalam menghadapi stres ataupun kebangkitan dari trauma yang dialami.

Peneliti dalam tulisan ini menyornti aspek pendidikan di Indanesia dimana pandemi Covid II ini turut memberi dampak bagi dunia pendidikan. Menteri Pendidikan, Kebudayaan, Riset \& Teknologi, Nadiem Makarim dalam pemaparannya dalam CNBC Indanesia Economic Update pada, Senin (II/7/2021) mengungkapkan bahwa Sejak pemberlakuan pembelajaran secara daring pada tahun 2020 yang lalu, tantangan yang dihadapi antara lain terkait dengan jaringan internet dimana tidak semua daerah di Indonesia memiliki koneksi internet yang baik. Hal ini meningkatkan disparitas (kesenjangan) dalam penggunaan internet untuk proses pembelajaran terutama antara daerah perkotaan dan pedesaan. Selain itu, ketersediaan teknologi, informasi, dan komunikasi (TIK) baik di sekolah maupun rumah tangga juga menjadi tantangan tersendiri. Ada sekolah-sekolah yang cepat tanggap dalam beradaptasi dengan perubahan metode pembelajaran ini, namun masih banyak sekolah yang kurang dapat beradaptasi dengan baik dalam aspek TIK ini. Wahana Visi Indanesia dalam survei terhadap 3.000 anak di 30 provinsi pada 2 sampai ZI April 2020 menemukan adanya pengaruh emosional terhadap anak dalam penerapan pembelajaran daring. Survei tersebut menjelaskan bahwa situasi keluarga juga berdampak pada emosional anak. Murid juga banyak yang kesulitan pembelajaran online yang hanya difokuskan pada pemberian tugas tanpa jadwal yang teratur. Selain itu, banyak siswa dari kelas menengah ke bawah yang mengalami dampak ekonomi (seperti pemutusan hubungan kerja) dan berimbas pada ketersediaan sarana prasarana belajar siswa (Santosa, 2020).

Secara lebih khusus, penulis menyoroti bagaimana mahasiswa memberi respon terhadap pembelajaran daring ini dengan berbagai tantangan dan kesulitan yang menyertainya. Berikut ini beberapa penelitian sebelumnya tentang kondisi-kondisi yang dialami mahasiswa dalam pembelajaran daring.

Survey oleh Kusnayat, Muiz, Sumarni, Mansyur dan Zaqiah (2020) terhadap mahasiswa Telkam University dan UIN SGD Bandung, menunjukkan bahwa sebagian besar dari reseponden mahasiswa (47\% untuk mahasiswa Telkom Universiy dan 72 \% untuk mahasiswa UIN SCD Bandung) mempersepsikan bahwa dosen memberikan tugas yang berlebihan dibandingkan dengan pembelajaran di kelas, selama perkuliahan daring dilakukan. Tugas yang berlebihan ini menjadi salah satu sumber stress bagi mereka. Hal ini diknnfirmasi lebih lanjut dimana, pada responden mahasiswa Telkom University, 70 \% mengaku sulit tidur ketika memikirkan tugastugas tersebut. Pada responden mahasiswa dari UIN SGD Bandung, 50 \% mengaku mengalami kesulitan tidur 
ketika memikirkan tugas-tugas tersebut. Lebih lanjut, sebanyak 34 \% mahasiswa Telkom University merasa kesulitan menggunakan aplikasi pembelajaran online, dan 31 \% mahasiswa UIN SGD Bandung mengalami kesulitan yang sama. Ketika dihadapkan dengan pernyataan "Saya lebih suka perkuliahan tatap muka", sebanyak 90 \% responden mahasiswa Telkom University dan 94\% responden mahasiswa UIN SGD Bandung setuju dengan pernyataan tersebut.

Survey lain yang dilakukan oleh Harahap, Harahap, dan Harahap (2020) terhadap 300 arang mahasiswa UINSU Medan dalam masa perkuliahan daring, menunjukkan bahwa sebanyak 39 mahasiswa (13\%) yang memiliki tingkat stress akademik kategori tinggi, sebanyak 225 mahasiswa (75\%) memiliki tingkat stress akademik pada kategari sedang, dan sebanyak 36 mahasiswa (12\%) memiliki tingkat stress akademik yang berada pada kategori rendah. Dapat disimpulkan, bahwa sebagian besar responden mahasiswa mengalami stress dalam mengikuti perkuliahan daring.

Beberapa hasil penelitian di atas menunjukkan bahwa dalam menjalani proses pembelajaran daring, mahasiswa mengalami berbagai situasi sulit, seperti masalah, hambatan, dan lainnya yang dapat menimbulkan stress, dan memberi dampak negatif bagi kesehatan psikologis maupun fisik. Maka dari itu, perlu memiliki kemampuan untuk mengatasi berbagai situasi sulit yang terjadi. Dengan kata lain, dibutuhkan resiliensi dalam diri mahasiswa agar dapat mengatasi berbagai kondisi yang dapat memberikan tekanan psikalogis ini.

Berdasarkan pemaparan latar belakang di atas, peneliti tertarik untuk melakukan penelitian terkait kondisi resiliensi dari para mahasiswa selama proses pembelajaran daring.

\section{METDDE PENELITIAN Rancangan}

Rancangan penelitian ini adalah penelitian survey dengan pendekatan kuantitatif deskriptif. Adapun tujuan dari penelitian ini adalah untuk memperoleh gambaran mengenai keadaan resiliensi mahasiswa selama pembelajaran daring.

\section{Subjek Penelitian}

Subjek penelitian dalam penelitian ini adalah mahasiswa aktif pada tahun ajaran 2019/2020, yang berasal dari berbagai program studi dan universitas di pulau Sumatera, Jawa, dan Papua, sebanyak 730 orang (laki-laki = 13l arang; perempuan = 599 arang)

\section{Prosedur}


Pengumpulan data penelitian dilakukan dengan menyebarkan skala The Cannar-Davidsan Resilience Scale (CD-RISC) versi adaptasi, secara online. Periode pengumpulan data berlangsung dari bulan April sampai dengan Mei 2020.

\section{Instrumen}

Instrumen yang digunakan dalam penelitian ini adalah skala psikologi resiliensi, yang sudah diadaptasi dari The Cannar-Davidsan Resilience Sca/e (CD-RISC). CD-RISC dikembangkan aleh Connar \& Davidsan (2003) untuk mengukur resiliensi psikologis, melalui 5 dimensi yakni : 1) persanal campetence, high standard, dan tenacity (sebanyak 8 item), 2) Trust to one's instinct, tolerance af negative affect (sebanyak 7 item), 3) positive acceptance of change and secure relationship (sebanyak 5 item), 4) cantra/ (sebanyak 3 item), 5) spiritual influence (sebanyak 2 item). Dalam skala ini total terdapat 25 item pernyataan dengan pilihan jawaban dari skala I (sangat tidak sesuai) sampai skala 5 (sangat sesuai). Dalam penelitian ini, skala adaptasi terlebih dahulu diuji validitas dan reliabilitasnya. Berdasarkan hasil uji reliabilitas diperoleh kaefisien Alpha Cranbach sebesar 0.93 dan semua item dinyatakan valid (dengan korelasi antar item $\geq 0.3$ ).

\section{Teknik Analisis Data}

Adapun teknik analisis data yang digunakan antara lain, pertama, melakukan analisis deskriptif statistik untuk skar resiliensi dan skar masing-masing dimensi dari skala resiliensi yakni dengan menggunakan nilai rata-rata dan standar deviasi. Kedua, menggunakan statistika deskriptif dalam membuat kategarisasi terhadap skar resiliensi, dan skar masing-masing dimensi dengan tiga kategarisasi yakni tinggi, sedang, dan rendah.

\section{HASIL DAN PEMBAHASAN}

Hasil

Berdasarkan hasil analisis deskriptif statistik terhadap skor resiliensi total dan skar dimensi-dimensi dari resiliensi, seperti yang tertera dalam Tabel I di bawah ini, dapat dilihat nilai dari rata-rata dan standar deviasi untuk skar resiliensi dan skar dimensi resiliensi.

Tabel I. Statistik Deskriptif Resiliensi dan Dimensinya

\begin{tabular}{|l|c|c|}
\hline \multicolumn{1}{|c|}{ Variabel/Dimensi } & Rata-rata (Mean) & Standar Deviasi (SD) \\
\hline Resiliensi & \$6.24 & 14.75 \\
\hline $\begin{array}{l}\text { Dimensi persana/ campetence, high } \\
\text { standard, dan tenacity }\end{array}$ & 31.23 & 5.22 \\
\hline $\begin{array}{l}\text { Dimensi trust to ane's instinct, } \\
\text { tolerance af negative affect. }\end{array}$ & 26.12 & 4.56 \\
\hline
\end{tabular}


ISSN (print) : 2722-7316

e-ISSN : :2723-1275

https://ejournal.uhn.ac.id/index.php/humaniora

\begin{tabular}{|l|c|c|}
\hline $\begin{array}{l}\text { Dimensi positive acceptance of } \\
\text { change and secure relationship }\end{array}$ & 18.11 & 3.74 \\
\hline Dimensi control & 11.86 & 2.15 \\
\hline Dimensi spiritual influence & 8.92 & 1.30 \\
\hline
\end{tabular}

Berdasarkan hasil perhitungan kategorisasi data skar resiliensi, seperti yang tertera dalam Tabel 2 di bawah ini, bahwa dari keseluruhan partisipan penelitian, yang tergalong memiliki resiliensi yang tinggi sebanyak 474 arang (64.9\%), resiliensi yang tergolang sedang sebanyak 247 arang (33.8\%), dan resiliensi yang tergolong rendah sebanyak 9 arang (1.2\%).

Tabel 2. Kategorisasi Skar Resiliensi

\begin{tabular}{|l|c|c|}
\hline \multicolumn{1}{|c|}{ Kategarisasi } & Jumlah (n) & Persentase (\%) \\
\hline Tinggi & 474 & 64.9 \\
\hline Sedang & 247 & 33.8 \\
\hline Rendah & 9 & 1.2 \\
\hline Total & $\mathbf{7 3 0}$ & 100 \\
\hline
\end{tabular}

Berdasarkan hasil perhitungan kategarisasi data skor dimensi persanal campetence, high standard, dan tenacity, seperti yang dapat dilihat seperti dalam Tabel 3 berikut, bahwa dari keseluruhan partisipan penelitian, sebanyak 474 arang (64.9\%) tergolong tinggi dalam dimensi persana/ campetence, high standard, dan tenacity, terdapat sebanyak 243 orang (33.3\%) dengan dimensi persana/ campetence, high standard, dan tenacity yang sedang, dan ada sebanyak 13 arang (1.8\%) dengan dimensi persana/ campetence, high standard, dan tenacity yang tergolong rendah.

Tabel 3. Kategorisasi Skor Dimensi Personal competence, high standard, dan tenacity

\begin{tabular}{|l|c|c|}
\hline \multicolumn{1}{|c|}{ Kategorisasi } & Jumlah (n) & Persentase (\%) \\
\hline Tinggi & 474 & 64.9 \\
\hline Sedang & 243 & 33.3 \\
\hline Rendah & 13 & 1.8 \\
\hline Total & $\mathbf{7 3 0}$ & 100 \\
\hline
\end{tabular}

Berdasarkan hasil perhitungan kategorisasi data skor dimensi trust to one's instinct, tolerance of negative affect, seperti yang dapat dilihat seperti dalam Tabel 4 di bawah ini, bahwa dari keseluruhan partisipan penelitian, sebanyak 399 arang (54.7\%) tergalang tinggi dalam dimensi ini, terdapat sebanyak 318 arang (43.6\%) yang tergalong sedang dalam dimensi ini, dan ada sebanyak 13 arang (1.8\%) yang tergalong rendah dalam dimensi ini.

Tabel 4. Kategorisasi Skar Dimensi Trust to one's instinct, tolerance of negative affect

\begin{tabular}{c|c|c|}
\hline Kategarisasi & Jumlah (n) & Persentase (\%) \\
\hline Resiliensi Pada Mahasiswa Selama Pembelajaran Daring & \\
\end{tabular}




\begin{tabular}{|l|c|c|}
\hline Tinggi & 399 & 54.7 \\
\hline Sedang & 318 & 43.6 \\
\hline Rendah & 13 & 1.8 \\
\hline Total & 730 & 100 \\
\hline
\end{tabular}

Berdasarkan hasil perhitungan kategarisasi data skar dimensi pasitive acceptance of change and secure re/ationship seperti yang dapat dilihat seperti dalam Tabel 5 berikut, bahwa dari keseluruhan partisipan penelitian, sebanyak 350 arang (47.9\%) tergalong tinggi dalam dimensi ini, sebanyak 343 arang (47\%) yang tergolong sedang dalam dimensi ini, dan sebanyak 37 arang (5.1\%) yang tergolong rendah dalam dimensi ini.

Tabel 5. Kategorisasi Skor Dimensi Positive acceptance of change and secure relationship

\begin{tabular}{|l|c|c|}
\hline \multicolumn{1}{|c|}{ Kategorisasi } & Jumlah (n) & Persentase (\%) \\
\hline Tinggi & 350 & 47.9 \\
\hline Sedang & 343 & 47 \\
\hline Rendah & 37 & 5.1 \\
\hline Total & $\mathbf{7 3 0}$ & $\mathbf{1 0 0}$ \\
\hline
\end{tabular}

Berdasarkan hasil perhitungan kategorisasi data skor dimensi contro/seperti yang dapat dilihat pada Tabel 6 berikut, bahwa dari keseluruhan partisipan penelitian, sebanyak 437 orang (59.9\%) tergolang tinggi dalam dimensi ini, sebanyak 284 arang (38.9\%) yang tergolong sedang dalam dimensi ini, dan sebanyak 9 arang (1.2\%) yang tergolong rendah dalam dimensi ini.

Tabel 6. Kategorisasi Skar Dimensi Cantral

\begin{tabular}{|l|c|c|}
\hline \multicolumn{1}{|c|}{ Kategorisasi } & Jumlah (n) & Persentase (\%) \\
\hline Tinggi & 437 & 59.9 \\
\hline Sedang & 284 & 38.9 \\
\hline Rendah & 9 & 1.2 \\
\hline Total & 730 & 100 \\
\hline
\end{tabular}

Berdasarkan hasil perhitungan kategarisasi data skor dimensi spiritual influence seperti yang dapat dilihat seperti dalam Tabel 7 berikut, bahwa dari keseluruhan partisipan penelitian, sebanyak 636 arang (87.1\%) tergalong tinggi dalam dimensi ini, sebanyak 80 arang (I2.1\%) yang tergolong sedang dalam dimensi ini, dan sebanyak 6 arang (0.8\%) yang tergalang rendah dalam dimensi ini.

\section{Tabel 7. Kategarisasi Skar Dimensi Spiritual influence}

\begin{tabular}{|l|c|c|}
\hline \multicolumn{1}{|c|}{ Kategarisasi } & Jumlah (n) & Persentase (\%) \\
\hline Tinggi & 636 & 87.1 \\
\hline Sedang & 88 & 12.1 \\
\hline Rendah & 6 & 0.8 \\
\hline Total & 730 & 100 \\
\hline
\end{tabular}




\section{PEMBAHASAN}

Penelitian ini bertujuan memperoleh gambaran mengenai resiliensi pada mahasiswa, selama masa pembelajaran daring, yang di Indanesia sendiri mulai berlangsung sekitar pertengahan Maret 2020.

Dari hasil penelitian yang dilakukan terhadap 730 mahasiswa dari berbagai kampus di Indanesia, yang dilakukan pada rentang waktu dari April sampai dengan Mei 2020, diperaleh gambaran bahwa kemampuan dari para mahasiswa tersebut dalam mengatasi berbagai hambatan dan kesulitan yang dialami selama pembelajaran daring, secara umum berada pada kategari tinggi. Hal ini, ditunjukkan dari data yang menyimpulkan lebih dari separuh partisipan (64.9\%), berada pada ketegari tinggi. Sementara itu, sebanyak 33.8 \% dari partisipan tergolang dalam kategari sedang dan hanya sebagian kecil (1.2\%) yang berada pada kategori rendah. Data ini mengindikasikan bahwa, meskipun dalam situasi belajar daring selama pandemi, para mahasiswa menunjukkan kapasitas psikolagis dan kemampuan diri untuk mengatasi berbagai situasi sulit yang terjadi selama proses pembelajaran daring berlangsung. Dimana dalam pembelajaran daring ini, banyak situasi yang berpotensi untuk melemahkan gairah belajar dan mengganggu performa belajar, seperti kurangnya sarana prasarana seperti buku, laptop, dan lainnya ketika mahasiswa berada di daerah asalnya; jaringan internet yang kurang memadai; situasi di dalam keluarga atau rumah yang kurang kondusif; dan lain sebagainya. Namun, meskipun berbagai knndisi yang menekan tersebut terjadi, sebagian besar mahasiswa memiliki keyakinan kuat dan perspesi yang positif tentang kemampuan dirinya untuk mampu hadapi berbagai tuntutan dan kesulitan serta perubahan yang terjadi selama perkuliahan daring, mampu mengelola berbagai stress yang dialami sehingga tidak frustasi, mampu melihat sisi spiritual dari situasi sulit yang terjadi, dan bangkit dari keterpurukan atau situasi tidak nyaman yang dialami dalam situasi pandemi dan pembelajaran daring ini. Alva (1991) menggambarkan bahwa pelajar yang resilien sebagai individu yang tetap memelihara dan menjaga motivasi dan performanya bahkan ketika dihadapkan dengan situasi yang menekan maupun situasi yang berpotensi menurunkan performa belajar.

Dimensi persona/ campetence, high standard, dan tenacity, mencakup persepsi positif individu akan kemampuan dan kapasitas dirinya dalam mencapai tujuan-tujuan yang telah ditetapkannya meskipun terdapat kesulitan ataupun situasi yang menekan, bahkan kegagalan sekalipun (Connor \& Davidsan, 2003). Dari data kategorisasi skor dimensi ini, 64.9\% dari partisipan tergolong tinggi, 33.3\% yang tergolong sedang, dan 1.8\% yang tergolong rendah. Hal ini menunjukkan bahwa mahasiswa sangat optimis akan kemampuan dirinya dalam mencapai tujuan yang ditetapkan terkait situasi atau masalah dalam pembelajaran yang mereka alami selama 
pembelajaran daring. Hal ini menjadi satu kunci utama yang dapat mempengaruhi keberhasilan mereka mengikuti pembelajaran daring.

Dimensi trust to une's instinct, tolerance of negative affect merupakan kemampuan individu dalam mengambil inisiatif dalam menghadapi masalah yang dialami, memiliki naluri yang baik dalam upaya pemecahan masalah serta mampu mengelola emosi-emosi negatif yang dirasakan (Connor \& Davidsan, 2003). Berdasarkan hasil dari kategorisasi data, sebanyak 54.7\% partisipan tergolang tinggi dalam dimensi ini, 43.6\% yang tergolong sedang dan hanya 1.8\% yang tergolong rendah. Dengan demikian, mahasiswa yang mengikuti pembelajaran daring memiliki kecakapan dalam mengelola emosi negatif maupun stress yang mereka rasakan terkait berbagai kesulitan yang dialami.

Dimensi pasitive acceptance of change and secure relationship merupakan dimensi yang berkaitan dengan penerimaan yang positif dari individu akan perubahan-perubahan yang terjadi sehubungan dengan kesulitan atau masalah yang dialami, dimana hal ini dibarengi dengan perasaan yang nyaman dalam hubungan relasi dengan orang lain (Connar \& Davidsan, 2003). Dari hasil kategarisasi skar dimensi ini, sebanyak 47.9\% partisipan tergolong tinggi, $47 \%$ yang tergolang sedang, dan $5.1 \%$ yang tergolong rendah. Data ini menunjukkan bahwa terdapat penerimaan yang positif dari mahasiswa akan berbagai perubahan yang terjadi di masa pandemi Covid 19 ini terutama yang terkait dengan pembelajaran daring. Tentunya perubahan ini sulit pada awalnya, namun seiring dengan waktu dan dengan dukungan dari orang terdekat, dalam hal ini keluarga, dimana banyak mahasiswa yang akhirnya kembali ke rumah berkumpul dengan keluarga, dapat menjadi sumber dukungan sasial yang secara psikologis dapat menolong mahasiswa untuk melewati kesulitan-kesulitan yang dialami.

Dimensi contro/ berkaitan dengan keyakinan individu akan kapasitas dirinya untuk dapat mengarahkan dirinya sendiri dalam mencapai tujuan yang ditetapkan meskipun terdapat situasi-situasi sulit yang dialami (Connor \& Davidson, 2003). Berdasarkan hasil kategorisasi, diketahui bahwa 59.9\% dari partisipan tergolong tinggi dalam dimensi ini, 38.9\% tergolong sedang dan hanya $1.2 \%$ yang tergolong rendah dalam dimensi ini. Data ini menunjukkan keyakinan yang kuat dari mahasiswa akan kapasitas dirinya dalam mengendalikan dan mengelola energi dalam dirinya untuk mencapai tujuan-tujuan yang ditetapkannya, meskipun ada kesulitan atau situasi yang menekan. Hal ini sangat diperlukan dalam pembelajaran daring dimana mahasiswa perlu menilai secara positif akan kapasitas dirinya untuk mengelola dirinya dan menata lingkungannya sedemikian rupa, sehingga kesulitan apapun yang dihadapi terkait pembelajaran daring, dapat diatasi dengan baik. 
Dimensi spiritual influence berkaitan dengan keyakinan individu akan adanya suatu kuasa supranatural yang lebih besar dari dirinya sendiri, yang dapat menolongnya dalam menerima dan menghadapi masalah atau kesulitan yang dialaminya (โannar \& Davidsan, 2003). Berdasarkan hasil yang dipaparkan pada bagian sebelumnya, sebagian besar partisipan (87.1\%) tergolong dalam kategari tinggi untuk dimensi ini, sebanyak 12.1\% tergalong sedang, dan hanya $0.8 \%$ yang tergalong rendah. Hal ini mengindikasikan begitu kuatnya pemahaman dan keyakinan dari para mahasiswa akan kuasa supranatural yang mempengaruhi kehidupannya, dimana kepercayaan ini membantu mereka untuk menerima, beradaptasi, dan mengatasi masalah yang mereka hadapi. Kondisi ini bisa dikaitkan dengan keyakinan atau kepercayaan religius yang dimiliki oleh mahasiswa, dimana bangsa Indanesia dikenal sebagai bangsa yang beraneka ragam dalam hal agama dan kepercayaan, dan kehidupan keluarga, pribadi, dan sasial masyarakat Indanesia sangat dipengaruhi oleh keyakinan agama yang dianut.

Berdasarkan pemaparan di atas, dapat disimpulkan bahwa kandisi resiliensi mahasiswa secara umum berada pada kategari tinggi dan sedang, dan hanya sebagian kecil yang berada pada kategari rendah. Hal ini menunjukkan bahwa meskipun di dalam proses pembelajaran daring ada banyak tantangan atau kesulitan yang dialami oleh mahasiswa yang berpotensi untuk menimbulkan stress dengan berbagai gejala yang menyertainya, ternyata dalam proses penyesuaian terhadap masalah yang dihadapi, para mahasiswa memiliki kemampuan untuk mengatasi hal-hal tersebut. Dengan kata lain, mahasiswa mampu mengembangkan resiliensi dalam proses belajar daring.

Rutter (1987, dalam Kalil, 2003) mengemukakan bahwa resiliensi merupakan hasil dari upaya mengelola berbagai macam resikn atau hal yang berpotensi menimbulkan krisis dengan cara-cara yang positif, daripada menghindari resika tersebut. Resiliensi ini melibatkan faktor-faktor protektif yang memungkinkan individu untuk bertahan terhadap berbagai tekanan hidup yang dialaminya. Faktor protektif merupakan faktarfaktor patensial yang dapat mencegah dan menanggulangi berbagai hambatan, persaalan, dan kesulitan secara efektif (Kalil, 2003). Faktor protektif ini antara lain a) berbagai atribut pribadi individu seperti temperaman yang baik, pandangan pasitif terhadap diri sendiri, dan inteligensi; b) kualitas keluarga antara lain kohesivitas, kehangatan, keterlibatan keluarga dan harapan keluarga; c) keberadaan dan pemanfaatan sistem pendukung eksternal di luar keluarga.

Mahasiswa dengan atribut pribadi yang positif, akan lebih mampu untuk mempersepsi masalah atau kesulitan dengan cara pandang yang positif, sehingga melakukan upaya-upaya untuk mengatasi kesulitan tersebut secara efektif. Kualitas dukungan keluarga merupakan faktor yang krusial dalam mendarang 
mahasiswa untuk mampu mengatasi berbagai kesulitan dan hambatan yang dialami dalam pembelajaran daring. Keluarga yang terlibat aktif dalam proses pembelajaran selama daring dengan memberikan dukungan materil dan moril, akan mendorong mahasiswa untuk menilai dirinya sebagai pribadi yang memiliki daya atau energi dan kemampuan untuk atasi masalah dan kesulitan yang dialaminya. Keberadaan teman sebaya dan komunitas belajar atau komunitas sekolah/kampus yang suportif dapat menjadi sumber dukungan sasial yang penting bagi mahasiswa dalam menjalani dan mengatasi berbagai tantangan atau kesulitan yang dihadapi selama proses pembelajaran daring.

\section{KESIMPLLAN}

\section{Kesimpulan}

Berdasarkan hasil dan pembahasan yang diuraikan pada bagian sebelumnya, maka dapat diambil kesimpulan sebagai berikut:

I. Berdasarkan kategorisasi dari hasil skar resiliensi, diketahui bahwa terdapat 474 orang partisipan (64.9\%) dengan resiliensi yang tinggi, terdapat 247 orang (33.8\%) dengan resiliensi yang sedang, dan ada 9 arang (1.2\%) dengan resiliensi yang rendah.

2. Dalam dimensi persunal cumpetence, high standard, dan tenacity, sebanyak 474 orang (64.9\%) tergolong tinggi, sebanyak 243 orang (33.3\%) tergolong sedang, dan 13 arang (1.8\%) yang tergolong rendah.

3. Dalam dimensi trust to one's instinct, tolerance of negative affect, sebanyak 399 orang (54.7\%) tergolong tinggi, sebanyak 318 orang (43.6\%) tergolong sedang, dan 13 orang (1.8\%) tergolong rendah.

4. Dalam dimensi positive acceptance of change and secure relationship, sebanyak 350 orang (47.9\%) tergolong tinggi, sebanyak 343 orang (47\%) tergolong sedang, dan sebanyak 37 orang (5.1\%) tergolong rendah.

5. Dalam dimensi cantral, sebanyak 437 orang (59.9\%) tergolong tinggi, sebanyak 284 orang (38.9\%) tergolang sedang, dan sebanyak 9 orang (1.2\%) yang tergolong rendah.

6. Dalam dimensi spiritual influence, sebanyak 636 orang (87.1\%) tergolong tinggi, sebanyak 88 orang (12.1\%) tergolong sedang, dan sebanyak 6 orang (0.8\%) yang tergolong rendah.

\section{Saran}

Saran tearetis dari hasil penelitian ini adalah diperlukan penelitian lanjutan untuk mengeksplorasi berbagai faktor-faktor baik itu internal maupun eksternal, yang mempengaruhi 
perkembangan resiliensi, terutama di masa pandemi Covid II ini. Faktor internal dapat berkaitan dengan atribut-atribut kepribadian sementara faktor eksternal dapat berhubungan dengan dukungan keluarga, dukungan teman sebaya, dan lainnya.

Saran praktis yang dapat disimpulkan dari penelitian ini terkait perlunya berbagai upaya berkelanjutan untuk memelihara dan meningkatkan resiliensi pada mahasiswa, yang bisa diinisiasi aleh pihak universitas atau fakultas. Salah satu bentuknya adalah melalui pelatihan saft skills mengenai resiliensi dan keterampilan-keterampilan hidup lainnya yang erat hubungannya dengan resiliensi.

\section{DAFTAR PUSTAKA}

Alva, Sylvia. A. I991. Academic invulnerability amung Mexican American students: the impartance of protective resources and appraisals. Hisp.J.Behavioral Science, Volume I3, I Januari

Connar, Kathryn M. \& Davidson, Janathan R.T. 2003. Development Df A New Resilience Scale: The CannarDavidsan Resilience Scale (CD-R/SC). Depression and Anxiety, Volume 18

Everall, Robin D., Altraws, K. Jessica. \& Paulsan, Barbara. L. 2006. Creating a Future: A Study of Resilience in Suicida/ Female Adqlescents. Journal of Counseling \& Development, Volume 84

Grotberg, Edith. 1999. Cauntering depression with the five building blocks of ressilience. Reaching Today's Youth, Volume 4 Nomor 1

Harahap, Ade С.P., Harahap, Dinda P. Harahap, Samsul R. 2020. Analisis Tingkat Stres Akademik Pada Mahasiswa Selama Pembelajaran Jarak Jauh Dimasa Covid-IG, Jurnal Kajian Konseling dan Pendidikan Volume 3, Nomor I, Maret

Hendriani, Wiwin. 2018. Resiliensi Psikalogis, Sebuah Pengantar. Prenandamedia Group : Jakarta

Howard, Sue. \& Jhonsan, Bruce. 2000. Resilient and Nan-resilient Behaviar in Addlescents. Trends and Issues in Crime and Criminal Justice, Australian Institute of Criminology. http://citeseerx.ist.psu.edu/viewdoc/download?dai=|0.1.1.530.6457๕rep=rep|\&type=pdf

Kalil, Ariel. 2003. Family Resilience and Goad Child Dutcames. Wellington: Ministry of Social Development.

Reivich, Karen, \& Shatte, Andrew. 2002. The Resilience factor: 7 Esential Skills for avercaming life's inevitable obstac/es. New York: Braadway Books

Richardasn, Glenn. E. 2002. The metatheary of resilience and resiliency. Journal of Clinical Psychalogy, Volume 58. Nomar 3

Santosa, Ari B. 2020. Potret Pendidikan di Tahun Pandemi: Dampak CUVID-IY Terhadap Disparitas Pendidikan di Indonesia. CSIS Commentaries DMRU-D79-ID

Watnaya, Agus K., Muiz, Mohammad H., Sumarni, Nani, Mansyur, Agus S. \& Zaqiah, Qiqi Y. 2020. Pengaruh teknalogi pembelajaran kuliah anline di era covid-II dan dampaknya terhadap mental mahasiswa. EduTeach : Jurnal Edukasi dan Teknologi Pembelajaran, Volume I, Nomor 2, Juni

Zimmerman, Marc A., \& Arunkumar, Revathy. 1994. Resiliency Research: Implications for Schools and Palicy.

Social Policy Report Saciety For Research In Child Development, Volume 3, Nomor 4 